\title{
Wind and Water Dispersal of Wetland Plants Across Fragmented Landscapes
}

\author{
Hester Soomers, ${ }^{1,2}$ Derek Karssenberg, ${ }^{3}$ Merel B. Soons, ${ }^{4}$ Pita A. Verweij, ${ }^{5}$ \\ Jos T. A. Verhoeven, ${ }^{4}$ and Martin J. Wassen ${ }^{1 *}$
}

\begin{abstract}
${ }^{1}$ Department of Environmental Sciences, Faculty of Geosciences, Utrecht University, P.O. Box 80115, 3508 TC Utrecht The Netherlands; ${ }^{2}$ Natuurmonumenten, Regio Zuid-Holland en Zeeland, P.O. Box 29198, 3001 GD Rotterdam, The Netherlands; ${ }^{3}$ Department of Physical Geography, Faculty of Geosciences, Utrecht University, P.O. Box 80115, 3508 TC Utrecht, The Netherlands; ${ }^{4}$ Ecology and Biodiversity Group, Department of Biology, Utrecht University, P.O. Box 80058, 3508 TB Utrecht, The Netherlands; ${ }^{5}$ Energy and Resources, Utrecht University, Budapestlaan 6, 3584 CD Utrecht, The Netherlands
\end{abstract}

\begin{abstract}
Biodiversity in wetlands is threatened by habitat loss and fragmentation, of which agricultural activities often are a cause. Dispersal of plant seeds via wind and ditches (water) may contribute to connecting remnant wetland plant populations in modern agricultural landscapes, and help to maintain and restore biodiversity. We developed a spatially explicit model to assess the relative importance of dispersal by wind and dispersal by water through drainage ditches for two wetland plant species in agricultural landscapes: a typical wind disperser and a typical water-disperser. Simulation results show that the typical wind disperser had a much higher capability to disperse by wind (90th percentile $<30 \mathrm{~m}$ ) than the typical water-disperser (90th percentile $<2 \mathrm{~m}$ ). Surprisingly, the capability to disperse via water was similar for the two species: 90th percentile dispersal distances following a combination
\end{abstract}

Received 4 May 2012; accepted 18 October 2012 .

published online 12 December 2012

Electronic supplementary material: The online version of this article (doi:10.1007/s10021-012-9619-y) contains supplementary material, which is available to authorized users.

Authors Contribution: Soomers, H.: Conceived of or designed study, performed research, analyzed data, contributed new methods or models, wrote the paper. Karssenberg, D.: Contributed new methods or models, analyzed data. Soons, M. B.: Contributed new methods or models, wrote the paper. Verweij, P.A.: Performed research. Verhoeven, J. T. A.: Wrote the paper. Wassen, M. J.: Conceived of or designed study, wrote the paper.

*Corresponding author; e-mail: M.J.Wassen@uu.nl of wind and water dispersal were between approximately 100 and $1000 \mathrm{~m}$. Dispersal by water transported more seeds over long distances for both species. The main determinants for dispersal distance by water were roughness of the ditch (determined by, for example, bank vegetation) and the presence of obstructions (for example, culverts). Density or direction of the ditch network did not seem to affect water dispersal distances substantially. From a biodiversity conservation perspective, it would be most useful if areas with suitable riparian wetland habitat were intersected with a network of shallow ditches with a high roughness promoting seed deposition. These areas should then be connected to other suitable areas by a few regularly cleaned ditches with no obstructions and low seed trapping probability.

Key words: anemochory; Carex pseudocyperus; ditch; fragmentation; hydrochory; landscape configuration; Phragmites australis; seed dispersal; spatial model.

\section{INTRODUCTION}

Habitat destruction and habitat fragmentation have reduced large, continuous natural areas to smaller and less connected habitat patches globally. These patches contain smaller and more isolated populations of plants and animals, which often experience an increased risk of extinction (Fahrig 
2003). In fragmented, isolated habitats, seed dispersal can become limiting for the regional survival of species (Soons and others 2005; Ozinga and others 2009). The colonization of new habitats and gene flow between populations usually decrease with fragmentation (Nathan 2001), which is therefore considered a major threat to biodiversity (Fahrig 2003; Hanski 2005).

Agriculture is a widespread driver of fragmentation because approximately $40 \%$ of the world's land surface is now covered by agricultural fields such as croplands and pastures (Foley and others 2005) and areas of intensive agriculture are inhospitable for wild flora and fauna (Donald and Evans 2006). Still, populations of wild species can persist in fragmented habitat patches surrounded by an agricultural matrix (Donald and Evans 2006). For plants, exchange between fragmented habitats takes place by seed dispersal via wind, water, animals, and human activity. Plant seed dispersal via wind (anemochory) has been widely investigated in many ecosystems (for example, Greene and Johnson 1989; Tackenberg 2003; Soons and others 2004; Nathan and others 2011). Recent studies have also shown the importance of surface water as a dispersal vector for riparian plant species (that is, hydrochory; Boedeltje and others 2003; Boedeltje 2005; Jansson and others 2005; Gurnell and others 2006). However, few studies have tried to combine seed dispersal by wind and water.

In relatively wet landscapes or poorly drained soils, land drainage systems are often required for profitable agricultural production (Vaughan and others 2007). Therefore, agricultural landscapes are often dominated by numerous drainage or irrigation ditches (Moss 1983; Borger 1992; Bootsma 2000). These types of agricultural landscapes with an extensive network of ditches can, for instance, be found in the Mississippi River Basin, USA (Moore and Kröger 2011; Kröger and others 2011) and in the UK (Moss 1983; Davies and others 2008), Germany (Kahle and others 2008), the Netherlands (Blomqvist and others 2003), and other parts of Europe (for example, Pelacani and others 2008; Maljanen and others 2010). Although agricultural fields are unsuitable as habitat for most wild plants, the banks of these drainage ditches may serve as refuges for wetland plant species (for example, Bunce and Hallam 1993; Blomqvist and others 2006). However, habitat quality varies because it is often negatively affected by herbicides and fertilizers applied to adjacent modern farming systems. As a result, many plant species growing at ditch banks survive in local spatially fragmented populations (Geertsema and Sprangers 2002). The ditches themselves may function as dispersal corridors between subpopulations of hydrochorous wetland plants growing at ditch banks (Geertsema and others 2002; Milsom and others 2004; Soomers and others 2010).

Many riparian wetland plant species possess highly buoyant seeds that can float several weeks to several months (van den Broek and others 2005), enabling them to disperse effectively by surface water. However, water can only transport seeds to areas that are connected to the source area by surface water. Wind, on the other hand, can transport seeds to a wide range of sites distributed all over the landscape. Many wetland plant seeds can be dispersed both by surface water and by wind (Bouman and others 2000; Middleton and others 2006; Soons 2006). For semi-terrestrial or terrestrial wetland species that do not grow directly along the water body, wind dispersal will often be the first dispersal stage, enabling seeds to enter the water. Therefore, when investigating dispersal of wetland plant seeds in agricultural landscapes, both anemochory and hydrochory should be taken into account.

Seed dispersal distances by wind are investigated in many studies, either by experimental research or by (mechanistic) modelling (for example, Greene and Johnson 1989; Nathan and others 2002; Soons and Heil 2002; Tackenberg 2003; Soons and others 2004; Nathan and others 2011 ). However, dispersal distances by water are not well known and hydrochory studies focus mostly on seed transport through rivers. To our knowledge, only two studies (Beltman and van den Broek 2006; Soomers and others 2010) have experimentally determined hydrochorous dispersal ranges in drainage ditches. Moreover, to our knowledge, spatially explicit process-based models predicting seed dispersal via water have not yet been developed. We found only three studies that have attempted to model hydrochorous dispersal (Campbell and others 2002; Levine 2003; Groves and others 2009). None of the models, however, is spatially and temporally explicit or is applicable to standing or slow-flowing waters such as ditches, in which hydrochorous dispersal is driven by wind shear stress (Soomers and others 2010; Sarneel and others, in press).

Although it is known that declines in availability of dispersal vectors in landscapes affect species loss, and that this effect is species- and vector-specific (Ozinga and others 2009), it remains unclear what portion of species' dispersal kernels is determined by different vectors, and how this changes between landscapes and species with differing traits. Seed traits such as terminal velocity (that is, seed falling 
velocity in still air) or buoyancy are often used to assess whether species are potentially capable of long-distance dispersal via wind or water (Ozinga and others 2009; Thomson and others 2010). However, this results in rough estimations of dispersal distances only, and does not tell us anything about the spatial seed deposition pattern and the contribution of different vectors to this pattern in real landscapes. Thus, to understand (meta)population dynamics and spread and persistence of species in fragmented landscapes, more knowledge on spatial dispersal patterns in different landscapes and by complementary vectors is needed.

The aim of this study is to analyze how dispersal of plant seeds via both wind and water contributes to the deposition patterns of seeds across agricultural landscapes. For this purpose, we developed a temporally and spatially explicit, process-based, coupled anemochory-hydrochory model. To parameterize and validate the model, we performed experiments in which we released and tracked seeds and representative seed mimics. Although animals and humans may also disperse seeds of wetland plant species (Strykstra and others 1997; Soons and others 2008; Wichmann and others 2009), we do not include them as dispersal vectors in our study because their effects on dispersal are as yet less understood.

We investigated for two ditch bank species, one representative of typical wind dispersers and the other of typical water-dispersers, how their deposition patterns differ between several agricultural landscape matrices. Using the anemochory-hydrochory model, we address the following research questions: (i) what is the relative contribution of wind dispersal and water dispersal to seed dispersal distances in landscapes with different configurations of drainage ditches and (ii) to what extent do system characteristics of the landscape (that is, ditch direction, density, roughness, and obstructions) determine the dispersal distances of seeds? Our results provide new insights into the relative importance of wind and water dispersal in agricultural landscapes and how different landscape characteristics and features determine deposition patterns of seeds across these landscapes.

\section{Methods}

\section{Study System}

We simulated anemochorous and hydrochorous dispersal of two wetland species in schematized agricultural landscapes consisting of meadows or agricultural fields interspaced by a network of drainage ditches. In the Netherlands, as in many other countries, the ditches in such systems are usually linear and narrow ( $<3 \mathrm{~m}$ wide), and parallel to each other, and are connected to each other and to larger canals by perpendicular ditches or canals. Together, these ditches and canals form a network for discharging excess water from precipitation and groundwater. The water in the ditches is slowflowing to stagnant which is essentially different from rivers and streams. Because of these low flow rates, both wind and water dispersal in these ecosystems are wind-driven (Soomers and others 2010; Sarneel and others, in press): wind shear stress on the water's surface drives the transport of hydrochorous seeds. In nature reserves (such as our experimental site Westbroekse Zodden; see Appendices B and $\mathrm{C}$ in Online publication) or at sites with agrienvironmental schemes (Donald and Evans 2006), the ditches and ditch banks together form ecosystems that may support relatively species-rich aquatic, semi-aquatic, and terrestrial vegetation such as marsh marigold meadow, reed land, and sedge marsh (Van Strien and others 1989; Leng and others 2011; Hirose and Werger 1995). In the Netherlands, this type of agricultural and semi-natural landscapes mostly occurs on former peatlands. Before reclamation, fen vegetation types like marshes (f.i. SPARGANIO-GLYCERION, CICUTION VIROSAE, and PHRAGMITION AUSTRALIS alliances), fens dominated by large sedges (f.i CARICION GRACILIS and CARICION ELATEA alliances), and fens dominated by small sedges (f.i. CARICION DAVALLIANAE and CARICION NIGRAE alliances) were found in these areas (Lamers and others 2002). Nowadays, remnant fen vegetation in such areas is mostly concentrated at ditch banks. Species occurring in the Westbroekse Zodden, in reed lands along the ditches, are fen species such as Phragmites australis, Sparganium erectum, Typha latifolia, Carex acutiformis, Carex pseudocyperus, Juncus acutifiorus, Peucedanum palustre, Scutellaria galericulata, and Thelypteris palustris (Hirose and Werger 1995). The ditch banks may also harbor rarer species such as Calla palustris, Menyanthes trifoliata, and Veronica scutellata. A list of species of ditch banks in the agricultural landscape in the Netherlands (Province of ZuidHolland) is given by Blomqvist and others (2003).

For our study, we compared the dispersal of a helophyte with clear seed adaptations for hydrochorous dispersal (C. pseudocyperus L.) with the dispersal of a helophyte that appears primarily adapted to anemochorous dispersal ( $P$. australis (Cav.) Steud.). In agricultural areas in peat districts, both species are common at ditch banks or in shallow standing water. C. pseudocyperus can also be found at watersides such as the edges of lakes, ponds, and rivers and in terrestrializing fens and 
carr forest (Van der Meijden 2005). The species is a $0.5-1.0-\mathrm{m}$-tall perennial belonging to the Cyperaceae family that flowers during May and June. The dispersing units (hereafter termed "seeds"), ovoidellipsoid utricles, are 4-5 mm long and approximately $1 \mathrm{~mm}$ wide and have a beak of approximately $2 \mathrm{~mm}$ (Jermy and Tutin 1968). P. australis grows at watersides, in shallow water, and in reed marshes and has wide ecological amplitude; it occurs both in fresh and brackish waters and on eutrophic or mesotrophic soils. The species is 1.0$3.0 \mathrm{~m}$ tall and flowers from July until October. The plumed seeds are approximately $1.6 \times 0.5 \times$ $0.5 \mathrm{~mm}$ in dimension (Bouman and others 2000). The two study species represent a group of species primarily adapted to hydrochorous dispersal (C. pseudocyperus) and a group of species primarily adapted to anemochorous dispersal (P. australis), respectively (Table 1 ).

Seed dispersal experiments to parameterize and validate the model were executed in the Westbroekse Zodden (the Netherlands, N: $52^{\circ} 9^{\prime} 43^{\prime \prime}$, E: $\left.5^{\circ} 7^{\prime} 1^{\prime \prime}\right)$, a peatland area in the Vecht river plain in the central Netherlands. Details on these experiments are given in Appendices B and C of Online publication and in Soomers and others (2010). Climate in the Netherlands, and thus also in the experimental site, is temperate, with cool summers and mild winters.

\section{Model Structure}

We developed a dynamic, spatially explicit, coupled anemochory-hydrochory model. The model predicted dispersal densities of wind- and water-dispersed seeds in a schematized $2 \times 2$-km landscape surrounding a central source-population of wetland plants. Our simulation landscapes consisted of a raster of $1000 \times 1000$ cells, of $2 \times 2 \mathrm{~m}$ each. The central source-population covered 135 cells. All source plants were located along a ditch and not in the agricultural fields. One million seeds were shed from each source-cell throughout the seed shedding period. Primary dispersal took place by wind; seeds that were blown into a ditch after wind dispersal dispersed further by surface water. During transport by surface water, seeds may get captured and may become mobile again until they finally sink if they are not captured by the ditch bank vegetation permanently. The model used a time step of 1 day and ran from July 1 until April 30 the next year. This end date was chosen because it was assumed that seeds germinate in spring (Bewley 1997), and are then not transported any further. The seed shedding season was assumed to be from July 1 to the 31 of
August with an assumed uniform seed shedding distribution throughout this 62-day period. Windand water-dispersal velocity were determined by wind speed and wind shear stress on the water surface, respectively, and therefore varied from day to day according to meteorological data. Outside the seed shedding season, water dispersal of seeds that had reached the water continued to take place. The model was developed using the PCRaster Python modelling framework (Karssenberg and others 2007).

\section{Anemochory Module}

To simulate wind dispersal distances for the two model species, the mechanistic Markov chain model for Synthetic Turbulance Generation, adjusted for grassland ecosystems (hereafter: STG model) (Soons and others 2004), was used. The STG model is a coupled Eulerian-Lagrangian stochastic dispersal model, which assumes that the change in position and velocity of a seed transported by wind is described by a Markov chain process. It realistically simulates fluctuations in both horizontal and vertical wind velocities, which results in an accurate prediction of dispersal distances by wind, as has been shown for grasslands and forests. Details on this model are given by Nathan and others (2002) and Soons and others (2004). Here, we will restrict ourselves to describing how we used the model in the coupled anemochory-hydrochory model.

As running the STG model for each individual seed in our simulations was not feasible, we used the STG model to calculate dispersal distance frequency distributions for 11 classes of average daily horizontal wind speeds (wind speeds $0-11 \mathrm{~m} / \mathrm{s}$, class width $1 \mathrm{~m} / \mathrm{s}$ ). For each average daily wind speed class, the frequency distribution was calculated by simulating wind dispersal of $10^{4}$ seeds. For each seed, a horizontal wind speed was drawn from a frequency distribution of 10 -min average wind speeds of the respective wind speed class (data from KNMI 2011). Furthermore, for each seed, terminal velocity $v_{\text {term }}(\mathrm{m} / \mathrm{s})$ was drawn from a normal distribution $V_{\text {term }} \sim N\left(\bar{x}_{v_{\text {term }}}, s_{v_{\text {term }}}^{2}\right)$, and seed release height $h_{0}(\mathrm{~m})$ was drawn from a uniform distribution $H_{0} \sim U\left(\min _{h_{0}}, \max _{h_{0}}\right)$, where $\bar{x}_{v_{\text {term }}}, s_{v_{\text {term }}}^{2}$, $\min _{h_{0}}$, and $\max _{h_{0}}$ were measured as described below (parameterization). These frequency distributions were then used as input for the coupled anemochory-hydrochory model.

The coupled anemochory-hydrochory model retrieved daily average wind speed and wind direction for each time step (a day). All seeds that were shed at the time step were distributed in the 


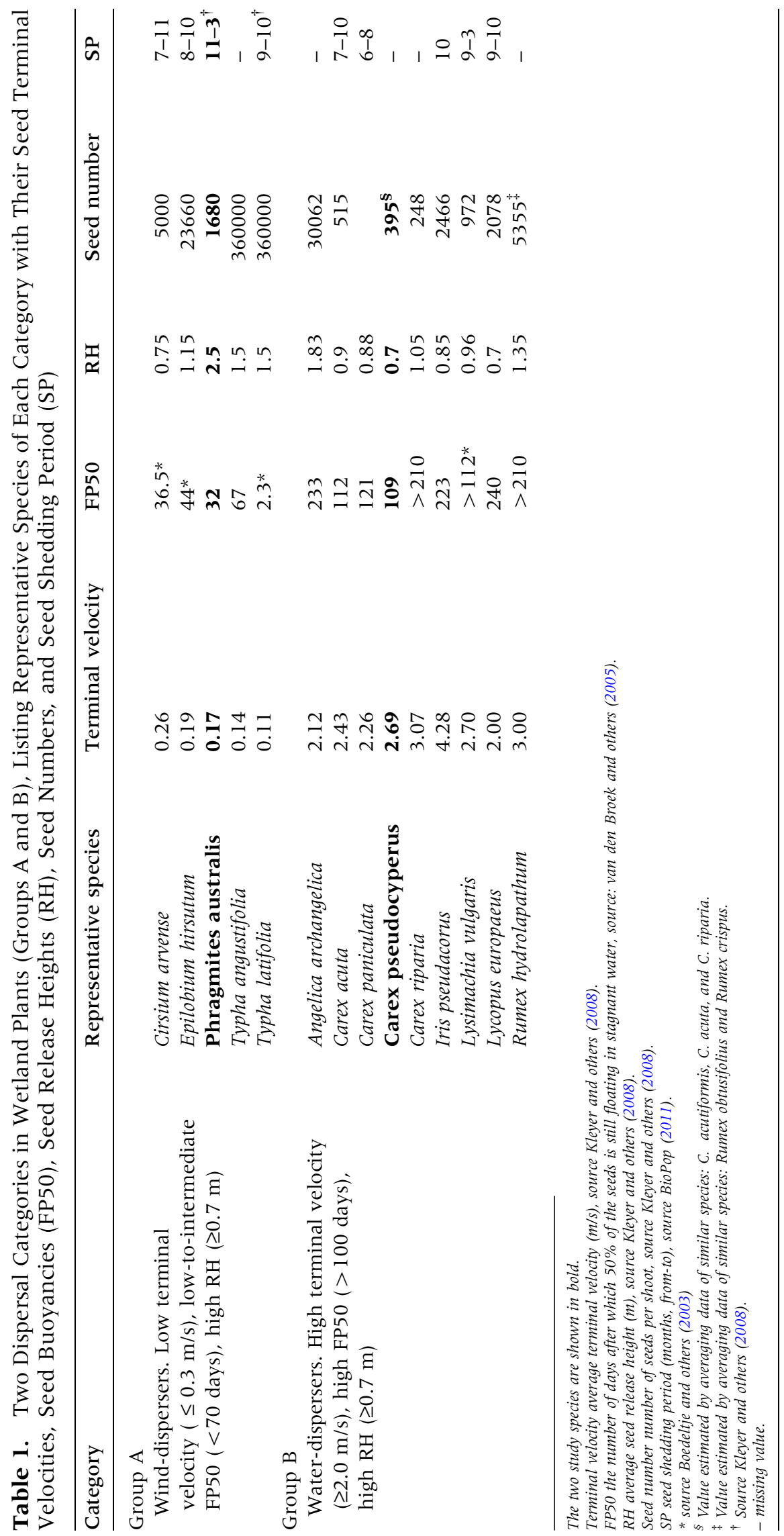


direction of the wind at that time step, and according to the frequency distribution of dispersal distances belonging to the daily average wind speed of the time step. We used actual daily wind data for 2009, location De Bilt, the Netherlands. This year was selected because it is representative for the years 2000-2010 (KNMI 2011).

Wind-dispersed seeds that ended up in "landcells" remained there, whereas those that were blown into ditch cells were consecutively transported via the network of ditches. Ditch cells into which wind dispersed seeds were blown are hereafter called source water cells.

\section{Hydrochory Module}

As a full individual-based modelling approach, where processes are described at the level of individual seeds, is not feasible at our scale of interest, we tracked homogeneous packages of seeds. For each time step and each grid cell, a package was created containing those seeds in the grid cell at the start of the time step that have the same residence time in the water, that is, time in days as the seeds were blown into the ditch cell. Homogeneity of residence time within a package is required as sinking of seeds in a package was modelled as a function of residence time. Up to the end of the time step, seeds in a package were transported in the downwind direction through the network of ditches, with a speed $v_{t, i}$ that is variable between ditch cells $i=1,2, \ldots, n$. The value of $v_{t, i}$ is calculated for each time step $t$ and cell $i$ as a function of wind velocity at $t$ (see parameterization). During this transport process, a proportion $c$ of the seeds transporting through a cell was captured in each cell. The seed flux $F$ (number of seeds per day passing a location) of the package over each time step was modelled as

$$
\frac{\partial F}{\partial x}=-c F
$$

in which $x$ is downwind distance along the ditch (in unit cell length of $2 \mathrm{~m}$ ) and $c$ is capture proportion per cell.

After seed transport and capture, a proportion $p$ (permanent capture probability) of the captured seeds remained permanently in the cell in which they were captured, whereas the rest of the captured seeds became mobile again. Subsequently, ratio $r_{t, t s}$ (sinking ratio) of the seeds that were mobile sink, whereas the remaining mobile seeds were transported further the next time step. These processes are described in Appendix A of Online publication.

\section{Parameterization}

\section{Anemochory}

The STG model was parameterized using input values given in Table 2 . Vegetation characteristics were chosen to represent a reed-land shoreline community in a fen meadow nature reserve. Vegetation leaf area index (LAI) values were adapted from Hirose and Werger (1995). Details on the experimental setup are described in Hirose and Werger (1995). We measured vegetation height at (and averaged for) six representative ditch banks in the fen meadow nature reserve the Westbroekse Zodden (N: $\left.52^{\circ} 9^{\prime} 43^{\prime \prime}, \mathrm{E}: 5^{\circ} 7^{\prime} 1^{\prime \prime}\right)$ in the Netherlands. Average seed release height was taken from Van der Meijden (2005). Terminal velocity was determined using an experimental setup conforming to Soons and Heil (2002). For this purpose, drop time was measured for 10 seeds randomly selected from four different populations situated in the central Netherlands.

Table 2. Parameter Values for Wind Dispersal Module

\begin{tabular}{|c|c|c|c|}
\hline & C. pseudocyperus & & P. australis \\
\hline$N_{\mathrm{c}}$ & \multicolumn{3}{|c|}{$1,000,000$} \\
\hline Number of source cells & \multicolumn{3}{|c|}{135} \\
\hline LAI $\left(\mathrm{m}^{2} / \mathrm{m}^{2}\right)$ & \multicolumn{3}{|c|}{3.16} \\
\hline$h(\mathrm{~m})$ & \multicolumn{3}{|c|}{1.17} \\
\hline$h_{0}($ minimum-maximum) $(\mathrm{m})$ & $0.5-1.0$ & & $1.0-3.0$ \\
\hline$D$ & \multicolumn{3}{|c|}{$0.61^{*}$} \\
\hline$z_{0}$ & \multirow{2}{*}{\multicolumn{2}{|c|}{$2.16 / 0.51 / 0.823$}} & \multirow[b]{2}{*}{$0.15 / 0.11 / 0.036$} \\
\hline$v_{\text {term }}($ mean $/$ minimum/SD $)\left(\mathrm{ms}^{-1}\right)$ & & & \\
\hline \multicolumn{4}{|c|}{$\begin{array}{l}\text { Values that were used for both species are placed in the middle. } \\
N_{c}=\text { number of seeds shed per cell per season; LAI = vegetation leaf area index; } h=\text { vegetation height; } h_{0}=\text { seed release height; } d=\text { zero-plane displacement height; } \\
z_{0}=\text { momentum roughness length; } v_{\text {term }}=\text { terminal velocity. } \\
\text { *Values are calculated by the STG model, based on LAI and } h .\end{array}$} \\
\hline
\end{tabular}


Table 3. Parameter Values, and (Regression) Equations Used to Determine Parameter Values, for the Water Dispersal Module

\begin{tabular}{|c|c|c|c|}
\hline \multicolumn{3}{|c|}{ C. pseudocyperus } & \multirow[t]{2}{*}{ P. australis } \\
\hline$v_{t, i}(\mathrm{~m} / \mathrm{s})$ & & $0.0256 \mathrm{NW}_{t, i, 1}+0.0232$ & \\
\hline $\mathrm{NW}_{t, i, 1}(\mathrm{~m} / \mathrm{s})$ & & \multicolumn{2}{|l|}{$\left|\cos \left(\mathrm{WD}_{t}-\mathrm{DD}_{i}\right)\right| \cdot \bar{U}_{t, 1}$} \\
\hline $\bar{U}_{t, 1}(\mathrm{~m} / \mathrm{s})$ & & \multicolumn{2}{|l|}{$\bar{U}_{t, 20} \ln \left(\frac{1-d}{z_{0}}\right) / \ln \left(\frac{20-d}{z_{0}}\right)$} \\
\hline$c$ & & \multicolumn{2}{|l|}{$((1-\alpha) * \beta) / 10000$} \\
\hline$\alpha$ & & \multicolumn{2}{|l|}{$\frac{1}{1+e^{-(2.14-0.036 H-1.36 F-1.42 M)}}$} \\
\hline$\beta$ & & \multicolumn{2}{|l|}{$e^{3.98+0.018 H+2.06 F+2.23 M}$} \\
\hline$c_{\text {culvert }}$ & & \multicolumn{2}{|l|}{0.96} \\
\hline$p$ & & \multicolumn{2}{|l|}{0.168} \\
\hline$r_{t, t s}$ & & \multicolumn{2}{|l|}{$a /[100-a((t-t s)-e)+a]$} \\
\hline$a$ & 0.61 & & 0.90 \\
\hline$e$ (days) & 33.1 & & 0.0 \\
\hline \multicolumn{4}{|c|}{ 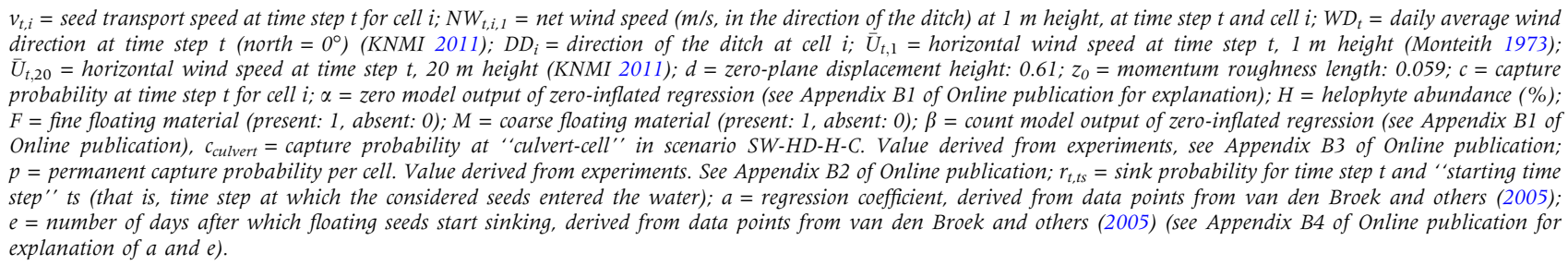 } \\
\hline
\end{tabular}

\section{Hydrochory}

Seed transport speed and direction are significantly positively correlated to wind speed and direction in ditches. No relation between water flow at middepth of a ditch and seed transport speed and direction was found by Soomers and others (2010). Therefore, seed transport speed and direction for each time step were determined by the average wind speed and direction at the corresponding days in 2009 (KNMI 2011). At ditch junctions, the transport direction most similar to the wind direction was chosen.

Seed transport speed per time step per ditch cell $\left(v_{t, i}\right)$ was calculated with use of a regression equation relating seed transport speed to net wind speed $\mathrm{NW}_{t}$ at $1 \mathrm{~m}$ height, given in Soomers and others (2010). Wind speed at $1 \mathrm{~m}$ height was derived from the observed wind speed at $20 \mathrm{~m}$ height following Monteith (1973) (Table 3). The net wind speed in the length direction of the ditch was calculated from the wind speed using vector calculations (Table 3).

The values of the parameters $p, c$, and $r_{t, t s}$ (see Appendix A of Online publication) were determined in five seed release and tracking experiments and two long-term seed mimic tracking experiments. In the seed tracking experiments,
1000 seeds were released and retraced in an 810$\mathrm{m}$-long ditch divided into 2-m sections (compare Soomers and others 2010 and Appendix Bl of Online publication). The two long-term seed mimic tracking experiments involved registering the location of 250 individually marked seed mimics, released in a 1037-m-long ditch in a fen meadow reserve (de Westbroekse Zodden) in the Netherlands, for every week during 9, respectively, 16 weeks. Equations resulting from analyzing these experiments, and other parameter values for the hydrochory module, are given in Table 3. Details on the experiments, statistical analyses, and parameterization are given in Appendix B 1-B4 of Online publication.

\section{Validation}

The hydrochory module was validated using the seed tracking experiments (described in Appendix Bl of Online publication and in Soomers and others 2010). Three out of eight randomly chosen repetitions of the experiment were not used for model parameterization but for model validation. We measured (or obtained from databases) in one ditch all the variables that drive seed transport via water in the model. These variables were obtained for each experimental section (that is, a 2-m-long 


\section{Orientation}

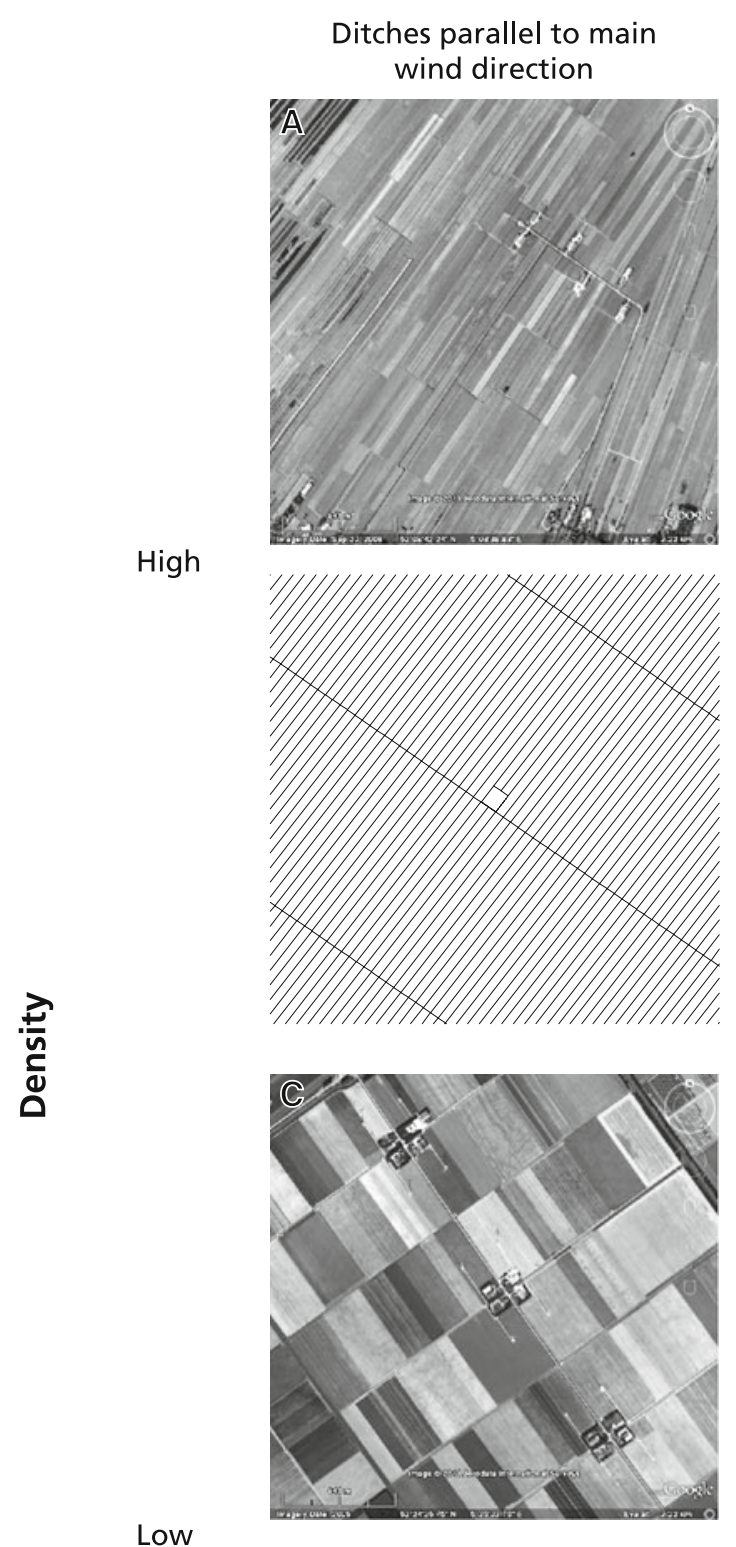

Ditches perpendicular to main wind direction
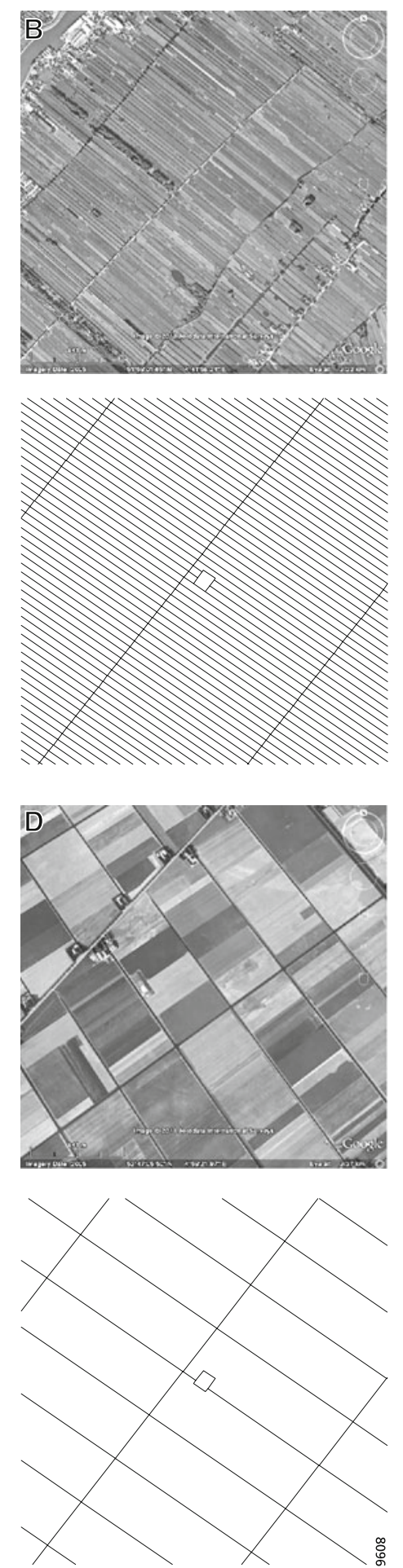

Figure 1. The four schematic simulation landscapes, and satellite images of examples of four Dutch landscapes dominated by agriculture on which the simulation landscapes were based.

A Scenario SW-HD: the majority of the ditches oriented southwestnortheast, with a high ditch density (Polder Achttienhoven, N: $52^{\circ} 09^{\prime} 42$, E: $5^{\circ} 08^{\prime} 38$ ), B scenario NW-HD: the majority of the ditches oriented northwestsoutheast, with a high ditch density (Polder Middelblok, N: $51^{\circ} 59^{\prime} 01$, E: $\left.4^{\circ} 41^{\prime} 58\right)$, C scenario SW-LD: the majority of the ditches oriented southwest-northeast, with a low ditch density (Southern Flevoland, N: $52^{\circ} 24^{\prime} 25$, E: $5^{\circ} 25^{\prime} 03$ ), and D scenario NW-LD: the majority of the ditches oriented northwestsoutheast, with a low ditch density (Noordoostpolder, N: $52^{\circ} 47^{\prime} 05$, E: $4^{\circ} 59^{\prime} 21$ ). Satellite images derived from Google Earth (2011).

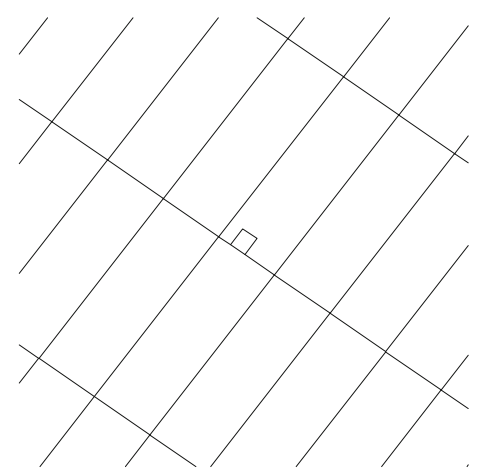

part of the ditch) which corresponds with one model-cell. In the model, 1000 seeds were released in the ditch at the same location as in the experiments.
The model was run with the settings of each experiment for two time steps. The percentage of released seeds located in each model-cell after two 
time steps of hydrochorous dispersal (48 h) was compared with the percentage of retrieved seeds in the experiment-sections $48 \mathrm{~h}$ after release. To assess model performance, seed percentages in the model-cells were related to seed percentages in the experiment sections using a Spearman correlation test for all experiments together. Furthermore, cumulative seed percentages for both the model and the experimental results were plotted against distance from release point for the three experiments separately. Details on the validation procedure are given in Appendix $\mathrm{Cl}$ of Online publication. The wind module (STG model) was validated earlier, as described by Soons and others (2004).

\section{Sensitivity Analyses}

To asses the sensitivity of the hydrochory module to changes in parameter values, each parameter of the module was changed with plus and minus 50 and $90 \%$, and the percentage change in median dispersal distance as a result of these parameter changes was calculated. Sensitivity analysis for the wind module (STG model) was performed earlier by Soons and others (2004).

\section{Scenarios}

We designed four schematic simulation landscapes representative for Dutch agricultural landscapes, in which we varied (1) ditch direction and (2) ditch density in the landscape (Figure 1). In two simulation landscapes (Figure 1A, C), the majority of the ditches were oriented from southwest toward northeast (along the main wind direction in the Netherlands). In the two other simulation landscapes, the majority of the ditches were oriented perpendicular to the main wind direction (Figure 1B, D). In either type of landscape, high and low ditch densities were simulated; this results in four scenarios (SW-LD, SW-HD, NW-LD, and NW$\mathrm{HD})$. In the high-density landscapes, the distance between parallel ditches was $40 \mathrm{~m}$, whereas in the low-density landscapes this was $300 \mathrm{~m}$. In agricultural areas, drainage ditches are usually connected with each other by ditches perpendicular to the others, to be able to drain excess water out of the area. Therefore, all simulation landscapes included three ditches that are oriented perpendicular to the other ditches.

These four simulation landscapes were each run for both C. pseudocyperus and P. australis and for two scenarios of ditch roughness: (1) roughness scenarios in which helophyte abundance along the bank (0-50 cm from the ditch bank) was $25.6 \%$ per cell (the average abundance in our experiments) and where no other obstructions were present in the ditch (hereafter called the highway scenario; final code-letter H, for example SW-HD-H), and (2) roughness scenarios in which helophyte abundance was $50 \%$, and fine floating material was present in the cells (hereafter called increased roughness scenario; final code-letters IR, for example SW-HD-IR). See Appendix Bl of Online publication for details on the roughness scenarios.

Finally, as agricultural landscapes tend not to have only open surface water connections but, instead, many surface water connections through culverts, we also simulated presence of culverts (that is, pipes below a field that connect ditches in case a road or a passage for cattle runs across a ditch). This was done in an additional scenario with two randomly placed culverts at each ditch-junction directly around the population and 1 randomly placed culvert at each other ditch-junction for both modelling species for the SW-HD landscape (code: SW-HD-H-C). See Appendix B3 of Online publication for details on the culvert scenario.

\section{RESUltS}

\section{Model Parameterization Results}

Seed release and tracking experiments revealed that presence/absence of fine or coarse organic material and helophyte abundance along the ditch bank were the major factors determining seed capture probability $(c)$ in our study system (Table 3 and Appendix Bl of Online publication). The seed release experiments in front of culverts showed that on average only 4\% (SD: 4.9) of seeds floated through a culvert (Table 3 and Appendix B3 of Online publication). Seed mimic experiments, in which individual seed mimics could be followed over longer time, revealed that part of the seeds that get captured at a certain day become mobile again, whereas another part becomes deposited permanently. This process could be described by an exponential decay function (Table 3; permanent capture probability $p$ and Appendix B2 of Online publication), which was incorporated in the hydrochory module of the model (Table 3 and Appendix B of Online publication).

\section{Model Validation Results}

For three repetitions of the seed release and tracking experiment, the observed cumulative seed percentages per distance after $48 \mathrm{~h}$ were plotted against the modelled percentages (see Appendix 


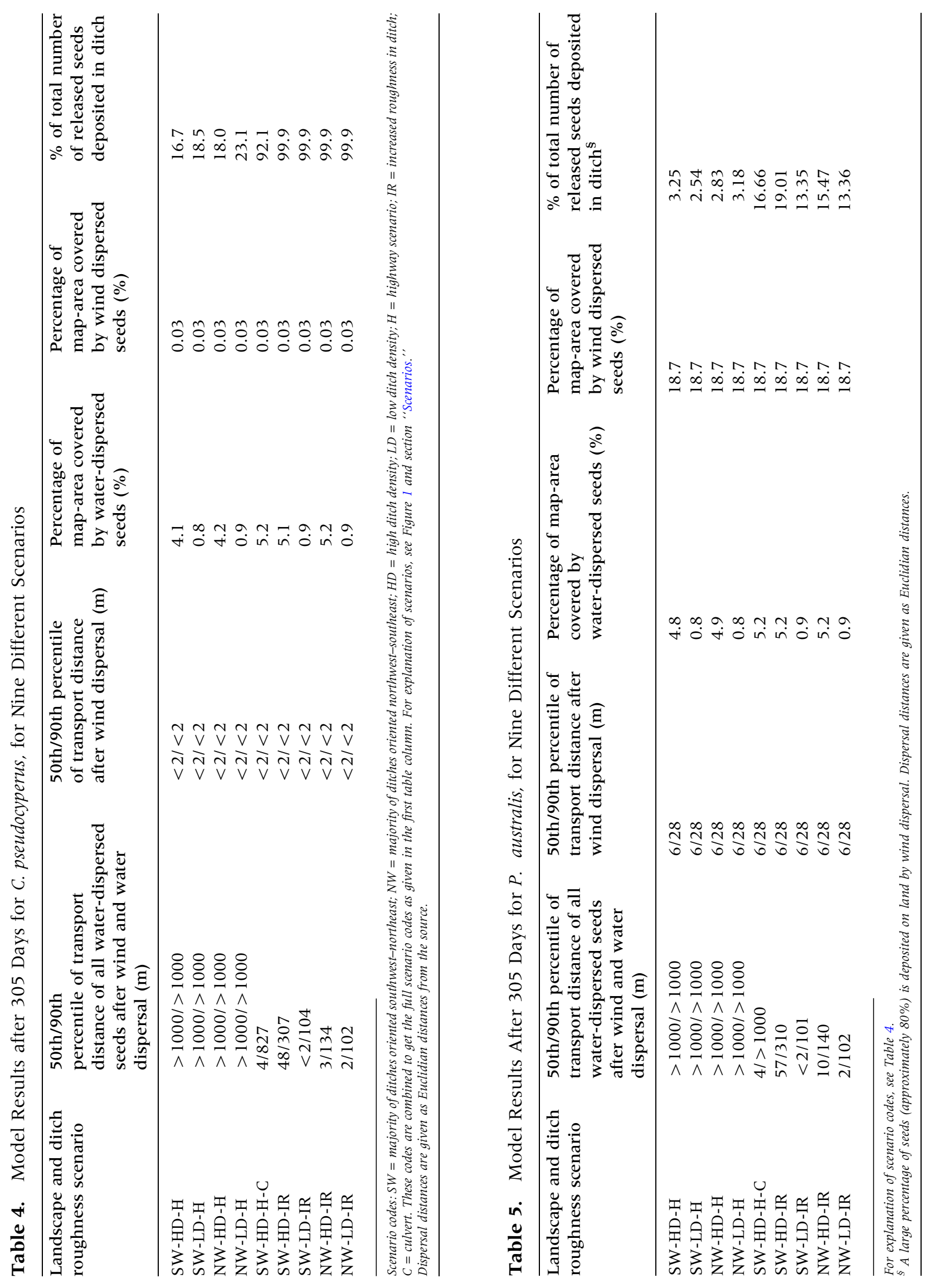




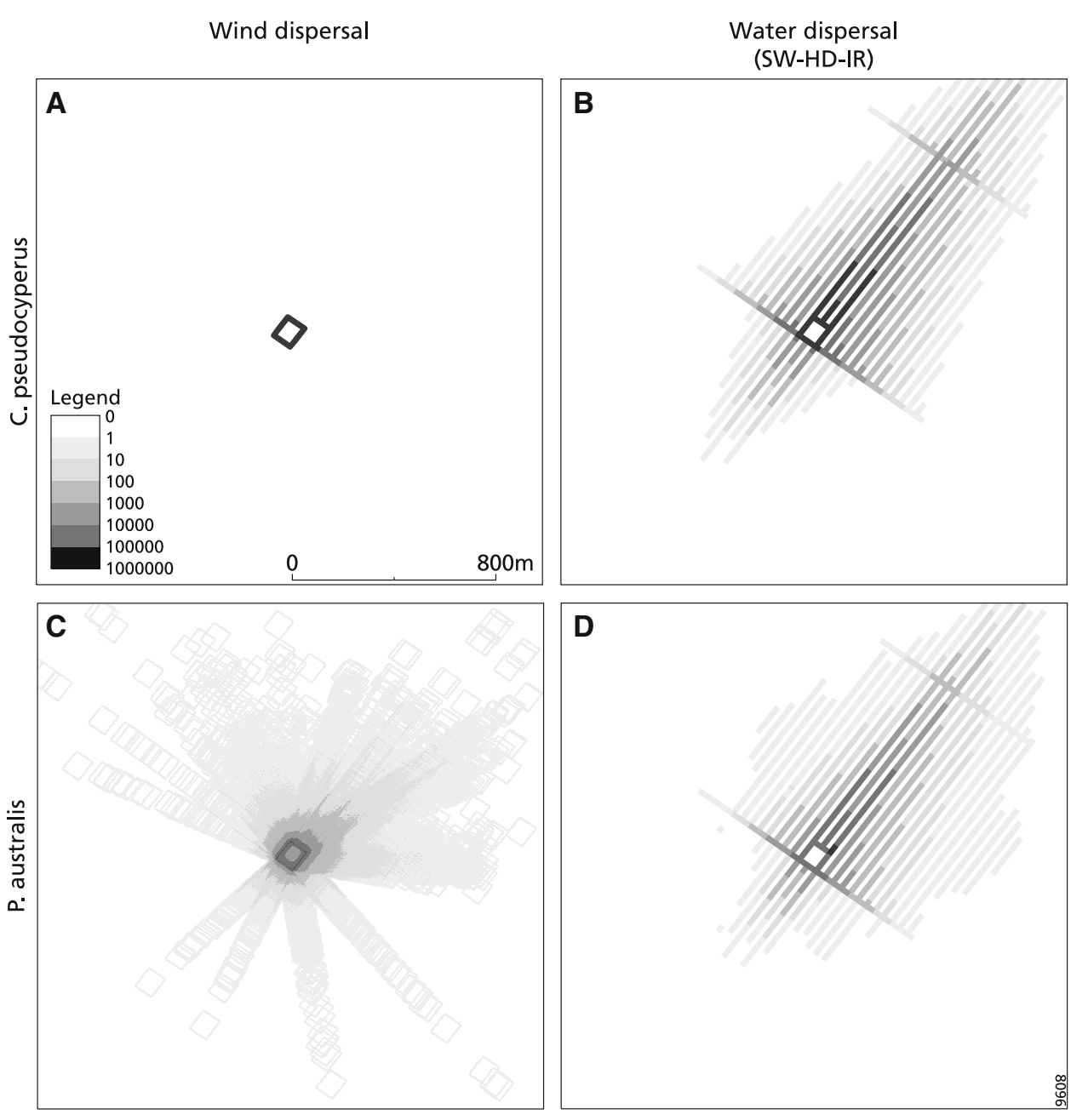

Figure 2. Simulated seed dispersal patterns

[number of seeds per cell $\left.\left(4 \mathrm{~m}^{2}\right)\right]$ for C. pseudocyperus (A, B) and $P$. australis $(\mathbf{C}, \mathbf{D})$.

A, C Seed distribution after wind dispersal.

B, D Seed deposition after wind- plus water dispersal (seeds that only dispersed by wind are not shown). All patterns are for the scenario with the majority of the ditches oriented in southwestnortheastern direction, high ditch density, and increased ditch roughness (SW-HD-IR). Winddispersed seeds of $P$. australis were deposited substantially further than wind-dispersed seeds of C. pseudocyperus (A vs. C). Water-dispersed seeds of both species were deposited with a similar pattern and at similar distances, but at longer distances than when only dispersed by wind.

C2-Figure C2.1 of Online publication). For one experiment, the simulated dispersal by water fit the experimental data very well. For the other two, the fit was less convincing. An overall correlation coefficient of 0.512 (Spearman correlation, $P<$ 0.01 ) was found when relating the percentage of seeds in cells in the model output to the observed percentage of seeds in experiment sections.

\section{Simulated Seed Dispersal}

Model simulations showed that water dispersal contributed strongly to the total dispersal kernels of both species (Tables 4, 5). Even for the typical wind disperser, $P$. australis, the simulated 90th percentile dispersal distances after wind-plus water dispersal were at least 3.5 times larger than the 90th percentile dispersal distances after wind dispersal only (Table 5).

The longest simulated wind dispersal distance for C. pseudocyperus was only $3 \mathrm{~m}$ (median and 90th percentile distances $<2 \mathrm{~m}$ ), whereas seeds of
$P$. australis dispersed by wind up to more than $1000 \mathrm{~m}$ (out of the model area) (median: $6 \mathrm{~m}$, 90th percentile: $28 \mathrm{~m}$ ) (Tables 4, 5; Figure 2). Consequently, the percentage of the model area at which wind-dispersed seeds were deposited differed greatly between the two species; for $P$. australis, this percentage was 623 times higher than for C. pseudocyperus (Tables 4, 5). Nevertheless, even for the typical wind disperser $P$. australis a large majority of seeds were, after only wind dispersal, deposited close to the source-population, in contrast to seeds that had been dispersed by both wind and water (Figures 2,4). The contribution of water dispersal to the total number of simulated seeds deposited at distances more than $100 \mathrm{~m}$ from the seed source was much higher than the contribution of wind dispersal, even for the typical wind disperser P. australis (Appendix D-Figure D1).

For $P$. australis, $18 \%$ of the modelling area was occupied by wind-dispersed seeds after 305 time 
steps, which was at least 3.5 times higher than the percentage of the area at which water-dispersed seeds (that had been previously dispersed by wind) had deposited. This was also true for landscapes with a dense ditch network; most of the simulated seeds landed on land. For C. pseudocyperus, however, the percentage of model-cells in which winddispersed seeds were present after deposition was much lower than that for water-dispersed seeds, because wind dispersal distances for this species were extremely short.

As we assumed the plants of the modelled source-population would grow at the ditch-edge and because simulated wind dispersal distances were very short for C. pseudocyperus, results show that more than $99 \%$ of its seeds entered the water. For $P$. australis, a higher percentage of seeds landed at "land-cells" after wind dispersal and thus did not enter the water. Therefore, the percentage of C. pseudocyperus seeds that were deposited at the ditch bank after water dispersal was structurally higher compared to $P$. australis (Tables 4, 5). Nevertheless, the percentage of the area covered by seeds deposited after water dispersal (excluding the seeds that only dispersed by wind) was similar for both species. Although buoyancy of $P$. australis seeds is much lower than for C. pseudocyperus seeds, simulated water dispersal distances and spatial patterns were also similar for the two species (Tables 4, 5; Figure 2).

For both species, simulated overall dispersal distances were highest for the landscape with a high ditch density and a ditch orientation parallel to the main wind direction (SW-HD), which both promote long-distance dispersal by water. Nevertheless, spatial patterns did not differ markedly between the four landscapes differing in ditch orientation and density (Figures 3,4). Orientation of ditches perpendicular to the main wind direction did not hinder seeds from dispersing in the main wind direction. The seeds even reached the ditches furthest away from the source-population within the simulated dispersal period (Figure 4).

Increasing ditch roughness or placing culverts in the ditch and thereby increasing seed capture probability had a much higher impact on the simulated dispersal distances than the effect of spatial orientation or density of ditches (Tables 4, 5; Figure 3). The limiting effect of culverts on the dispersal distance was more pronounced for C. pseudocyperus than for $P$. australis (Tables 4, 5; 90th percentile water dispersal distances), because $P$. australis seeds were able to pass over culverts by wind. This is in agreement with results of the sensitivity analyses for C. pseudocyperus, which

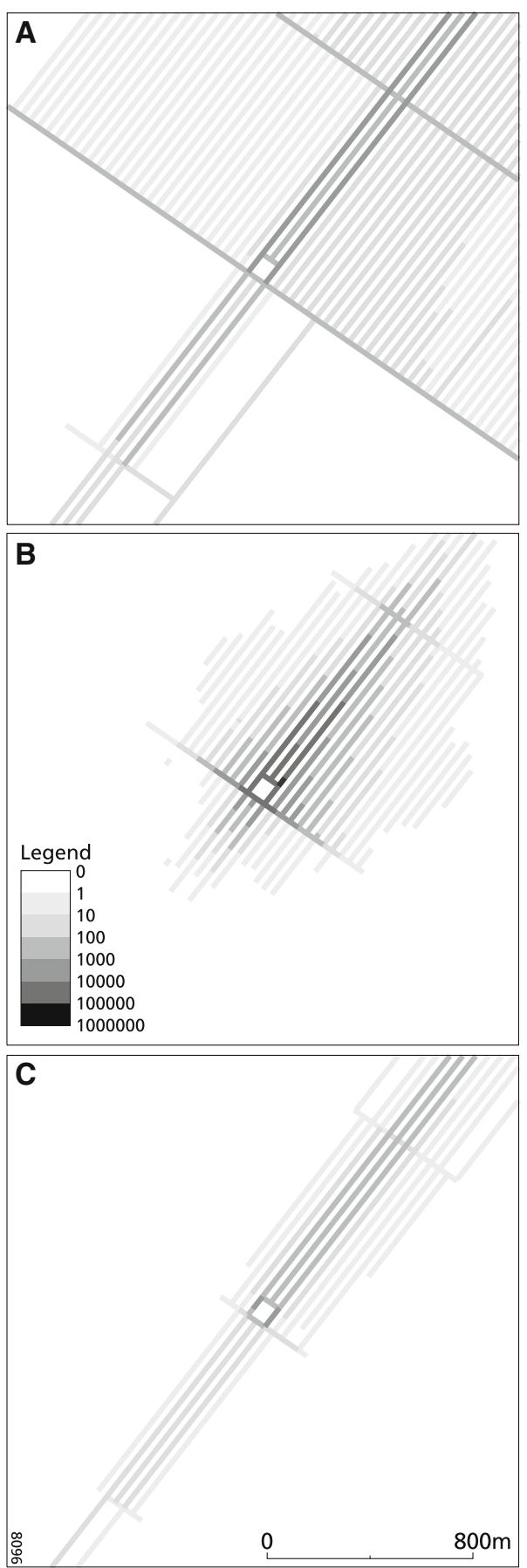

Figure 3. Simulated seed dispersal patterns of seeds deposited after wind-plus water dispersal (seeds that only dispersed by wind are not shown) for $P$. australis, SW-HD landscapes. A Highway scenario, B Increased roughness scenario, C Culvert scenario. Seeds in the highway scenario (low ditch roughness) were deposited in a wider spatial pattern than when ditch roughness was increased or obstructions (culverts) were introduced. In the latter two scenarios, more seeds stayed within the modelling area, which explains the higher seed densities per cell. 

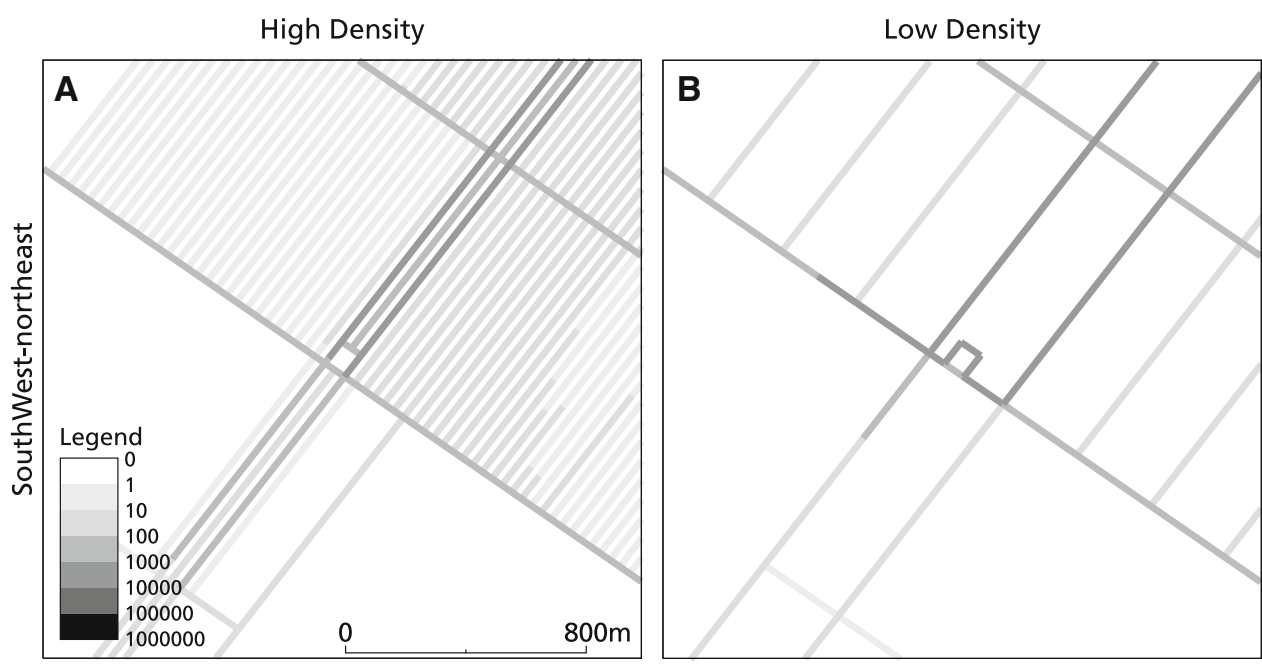

Fig. 4. Simulated seed dispersal patterns of wind- and waterdispersed seeds (seeds that only dispersed by wind are not shown) of $P$. australis. Highway scenarios, all four landscapes. Low ditch densities (B, D) or an orientation of the majority of the ditches perpendicular to the main wind direction did not prevent water-dispersed seeds from travelling in the main wind direction
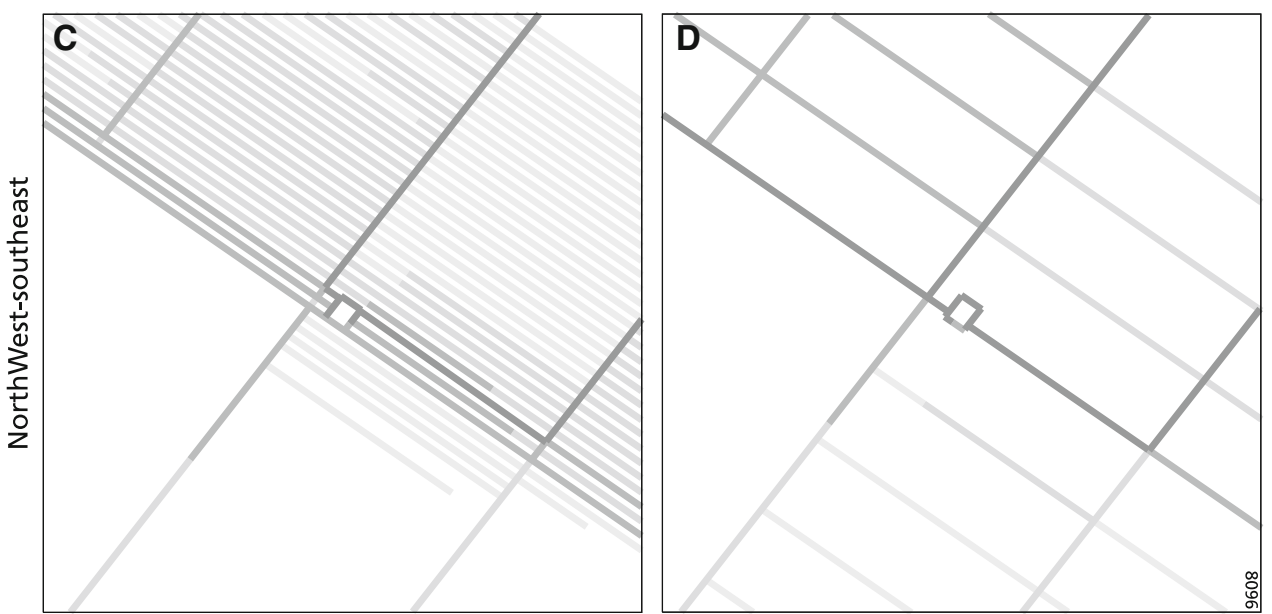

(C, D)

demonstrate that the model is hardly sensitive to changes in seed transport speed and seed buoyancy (Table 6). Seed capture probability and permanent seed capture probability are most important in determining hydrochorous seed dispersal distance for C. pseudocyperus.

\section{Discussion}

\section{Wind Dispersal versus Water Dispersal}

Our results show that typical wind dispersers can be transported over long distances by water, and may disperse by water over similar distances as typical water-dispersers. For river systems, comparable results were found by Säumel and Kowarik (2010), who revealed that hydrochory was an effective dispersal agent in wind-dispersed tree species in a German river, extending wind-related transport distances by several times. Our results show that hydrochory is likely to contribute considerably to the dispersal of wetland plant seeds across the agricultural landscape considered here, for both wind and water dispersal specialists. The general difference between water dispersal specialists (characterized by high seed buoyancy and high seed terminal velocity) and wind dispersal specialists (medium seed buoyancy, low seed terminal velocity) is that the former initially disperse by wind over very short distances and then greatly extend their range by water dispersal, whereas the latter disperse seeds throughout the landscape over medium to long distances by both mechanisms. Seeds of both plant types that end up in the water could disperse effectively via the network of ditches in agricultural landscapes, thereby not only multiplying their original wind dispersal distances but also ensuring dispersal to suitable ditch habitat.

The importance of hydrochory as a vector in wetland habitats was also demonstrated for a forested floodplain in USA by Schneider and Sharitz (1988), who found that 10-100 times as many cypress seeds and tupelo fruits were transported into each plot by water as by wind dispersal alone. Similarly, Jansson and others (2005) showed that along a Swedish river, $36-58 \%$ more species colonized 


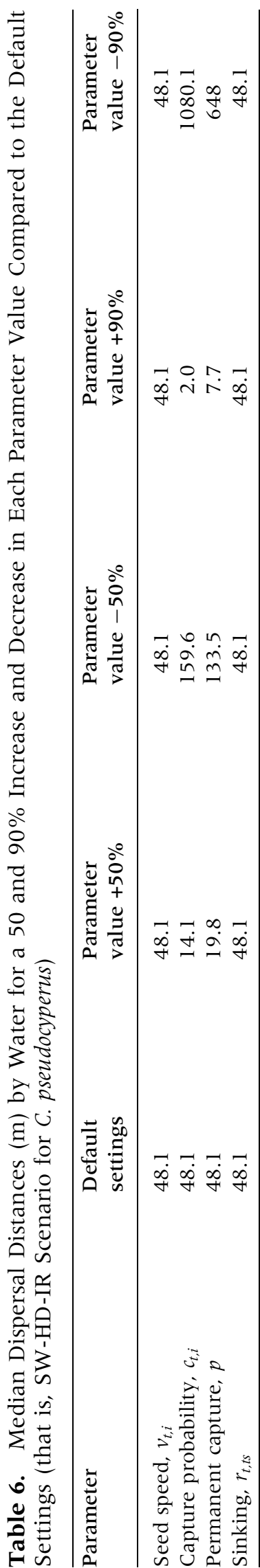

flooded plots (subjected to hydrochory) than unflooded plots that were only subjected to anemochory and zoochory. Our results thus strengthen the idea that hydrochory is very important in wetland plant population dynamics.

Notably, our results show that, after entering the surface water, seeds of wind dispersal specialists dispersed almost equally far by water as seeds of water dispersal specialists. This is likely to be a general finding, as seeds of most species that are adapted to wind dispersal also float well when they enter the surface water (Nilsson and others 2010). Seeds with very low terminal velocity and thus high ability for long-distance wind dispersal often have wings or hairs (Bouman and others 2000; Nilsson and others 2010), which also increase their ability to remain on the water by surface tension (Nilsson and others 2010). Although the seeds of such species rarely float as long as seeds of species typically adapted to hydrochory, our results show that seed buoyancy is not limiting hydrochorous dispersal distances on the scale of our study (up to $4 \mathrm{~km}^{2}$ and one autumn-winter season).

\section{Landscape Patterns and Ditch Roughness}

Besides the differences between wind and water dispersal, we investigated the effects of characteristics of the landscape (that is, ditch direction, density, roughness, and obstructions) on dispersal distances and patterns. Surprisingly, the orientation of the ditches relative to the main wind direction did not seem to be very important: hydrochorous dispersal is only slightly more efficient in landscapes with southwest-northeast-oriented ditch patterns, which is parallel to the main wind direction. As long as ditches are connected to each other by perpendicular ditches, a seemingly unfavorable main orientation of ditches does not largely limit dispersal distance. Although hydrochorous dispersal of floating seeds in stagnant waters is driven by wind, variations in wind direction throughout the (relatively long) dispersal season probably remove any strong directional effects. A decrease in ditch density had a somewhat greater effect, reducing dispersal throughout the landscape slightly. However, changing helophytic plant abundances or other obstructions in the ditches greatly affected model results. For the so-called highway scenarios the majority of the hydrochorous seeds left the modelling area, whereas for the scenarios with increased ditch roughness by plant material and for the scenarios with culverts at ditch crossings at least $90 \%$ of the seeds that had entered the water stayed within the modelling area within 
the simulated time period. The huge difference in the dispersal distances predicted by the highway scenario, on the one hand, and the increased roughness- and culvert scenarios, on the other hand, show that cleaning ditches or constructing alternative designs for culverts (for example, wider diameter, bridges) would probably greatly magnify realized hydrochorous dispersal distances. Considering our results, these measures would have a higher positive effect on dispersal capacity than any denser network of extra ditches or creating extra short-cuts between ditches.

\section{Model Performance}

The findings described above are very clear and robust to small $(<50 \%)$ changes in critical model parameters. The most sensitive parameters in the model are the seed capture probability $p_{t, i}$ and permanent capture $c$ (Table 6). To further improve the hydrochory module, these parameters should be quantified in more detail. It should be noted that both temporal and permanent seed capture probability parameters were not species-specific in our hydrochorous dispersal model. Seed size or shape might affect deposition probability (see Schneider and Sharitz 1988), and therefore dispersal experiments with different seed types should be performed to improve parameterization. Furthermore, considering the sensitivity of modelled dispersal to permanent capture probability, a reliable way to assess this parameter should be found. To quantify permanent capture probability, it is necessary to mark seeds individually. However, marking seeds individually is difficult for real seeds, and seed mimics do not necessarily behave as real seeds. Also, retracing real (usually small) seeds during a long period of time (preferably 1 year) is difficult, if not impossible. Alternatively, population genetic techniques could be used to calibrate and/or validate dispersal models (Ouborg and others 1999) over a large temporal and spatial scale. Summarizing, more field data, collected over large temporal and spatial scale, is needed to reliably parameterize especially seed capture probability. Still, model validation showed that the hydrochory module underestimated real water dispersal distances (see Appendix C2 of Online publication), meaning that the conclusion that dispersal via water ensures considerably larger dispersal distances than dispersal via wind appears valid despite model uncertainty.

Given the sensitivity of our model to the seed capture parameters and the limited extent of the experiments used to determine these parameter values, combined with the mediocre fit between observed and modelled data, conclusions on dispersal distances should be drawn carefully and focus on relative differences between scenarios, species or dispersal mechanisms and on general spatial patterns rather than absolute values. Nevertheless, Geertsema (2005), who investigated colonization and extinction events for riparian plant populations at ditch banks along arable fields, found that most colonization events took place within $50 \mathrm{~m}$ of the nearest conspecific population, but that colonization distances exceeding $200 \mathrm{~m}$ also occurred. These figures are in the same order of magnitude as the results of our increased roughness and culvert scenarios, after dispersal by wind and water. This may indicate that increased roughness/culvert scenarios give the most realistic estimates.

\section{Implications for Nature Conservation}

Despite the apparent potential for long-distance dispersal of hydrochorously dispersing seeds, Ozinga and others (2009) stress that species with adaptations for water dispersal are overrepresented among declining species. This is probably caused by the lack of connectivity between riparian habitats via water nowadays, caused by hydrological alteration, water works such as culverts, and the regulation of streams and rivers by dams and sluices. These obstructions are known to prevent effective hydrochorous dispersal via rivers; free-flowing rivers enable more efficient hydrochorous dispersal than artificially controlled rivers (for example, Andersson and others 2000; Jansson and others 2000; Merritt and Wohl 2006) and in fragmented landscapes dispersal has been shown to be a limiting factor in the development of aquatic and riparian vegetation after restoration measures (Brederveld and others 2011). Similarly, our results show that culverts greatly reduce water dispersal distances in agricultural landscapes, especially for water dispersal specialists, which are not able to overcome these barriers by initial long-distance wind dispersal. These results stress the importance of free-flowing connected water bodies for population connectivity and colonization and thus for habitat restoration at a catchment scale (see Verhoeven and others 2008), especially for species with seeds that are mostly dependent on surface water as a dispersal vector, considering their very limited wind dispersal ability. It is known that many plant seeds can also be dispersed by animals (zoochory: Clausen and others 2002; Soons and others 2008; Brochet and others 2010) or humans (Strykstra and others 1997; Wichmann and others 2009). Although such dispersal events are highly 
stochastic and difficult to track, it will be important to include them in future dispersal studies, to assess the relative importance of such dispersal events.

Besides the transport process, another aspect important for effective seed exchange between populations or for colonization is that seeds also need to deposit at places suitable for germination. The most favorable regional scale measure for seed exchange and colonization would be to create "dispersal highways" in areas where habitat quality is unsuitable for germination or establishment, and increase deposition probability through increased roughness in more suitable areas. The latter can, for instance, be realized by a less regular ditch cleaning regime in more natural areas, enabling helophytes to grow along the ditch banks, or creating seed "landing strips" consisting of ditch banks with a physical structure suitable for catching seeds (see Soomers and others 2010). In this way, the connectivity of a wetland ecosystem can be optimized (Verhoeven and others 2008). Note that ditches in natural areas should not drain deeply, to avoid desiccation of the habitat.

To summarize, our study suggests that in modern agricultural landscapes with a network of ditches in which hydrochory is driven by wind, water is an important dispersal vector for both typical wind and typical water-dispersers, whereas wind as a dispersal vector is only relevant for typical wind dispersers. Via wind seeds can disperse in any direction, whereas dispersal via water is restricted to the spatial lay-out of the surface water infrastructure. Nevertheless, dispersal distances by water are likely to surpass those by wind, even for typical winddispersing species. Adjustments to the landscape to optimize connectivity between remnant populations of wetland species could therefore focus on adjustments in the ditch network, as detailed above.

\section{ACKNOWLEDGMENTS}

We would like to thank Cees Wesseling for his support during model development. Furthermore, Florus Sibma and Saskia van de Venne are acknowledged for doing field experiments. Hester Soomers was funded by the Utrecht Centre of Geosciences. Merel Soons was funded by the Netherlands Organization for Scientific Research (NWO-MEERVOUD grant).

\section{OPEN ACCESS}

This article is distributed under the terms of the Creative Commons Attribution License which permits any use, distribution, and reproduction in any medium, provided the original author(s) and the source are credited.

\section{REFERENCES}

Andersson E, Nilsson C, Johansson ME. 2000. Effects of river fragmentation on plant dispersal and riparian flora. River Res Appl 16:83-9.

Atkins DC, Gallop RJ. 2007. Rethinking how family researchers model infrequent outcomes: a tutorial on count regression and zero-inflated models. J Fam Psychol 21:726-35.

Beltman B, van den Broek T. 2006. Het beperkte succes van Laagveenrestauratie. Landschap 22:173-9.

Bewley JD. 1997. Seed germination and dormancy. Plant Cell 9:1055-66.

Biopop. 2011. Biopop. Biologische Parameter des Populationsmanagements bei Pflanzen.

Blomqvist MM, Tamis WLM, Bakker JP, van der Meijden E. 2006. Seed and (micro)site limitation in ditch banks: germination, establishment and survival under different management regimes. J Nat Conserv 14:16-33.

Blomqvist MM, Vos P, Klinkhamer PGL, ter Keurs WJ. 2003. Declining plant species richness of grassland ditch banks-a problem of colonisation or extinction? Biol Conserv 109:391406.

Boedeltje G. 2005. The role of dispersal, propagule banks and abiotic conditions in the establishment of aquatic vegetation. PhD thesis. Radboud Universiteit Nijmegen, Nijmegen.

Boedeltje G, Bakker JP, Bekker RM, van Groenendael JM, Soesbergen M. 2003. Plant dispersal in a lowland stream in relation to occurrence and three specific life-history traits of the species in the species pool. J Ecol 91:855-66.

Bootsma MC. 2000. Stress and recovery in wetland ecosystems. PhD thesis. Universiteit Utrecht, Utrecht.

Borger GJ. 1992. Draining, digging, dredging; the creation of a new landscape in the peat areas of the low countries. In: Verhoeven JTA, Ed. Fens and bogs in the Netherlands: vegetation, history, nutrient dynamics and conservation. Dordrecht: Kluwer. p 131-71.

Bouman F, Boesewinkel D, Bregman R, Devente N, Oostermeijer G. 2000. Verspreiding van zaden. Utrecht: KNNV Uitgeverij.

Brederveld RJ, Jaehnig SC, Lorenz AW, Brunzel S, Soons MB. 2011. Dispersal as a limiting factor in the colonization of restored mountain streams by plants and macroinvertebrates. J Appl Ecol 48:1241-50.

Brochet AL, Guillemain M, Fritz H, Gauthier-Clerc M, Green AJ. 2010. Plant dispersal by teal (Anas crecca) in the Camargue: Duck guts are more important than their feet. Freshw Biol 55:1262-73.

Bunce RGH, Hallam CJ. 1993. The ecological significance of linear features in agricultural landscapes in Britain. In: Bunce RGH, Ryskowski L, Paoletti MG, Eds. Landscape ecology and agroecosystems. Boca Raton: Lewis Publishers. p 11-19.

Campbell GS, Blackwell PG, Woodward FI. 2002. Can landscapescale characteristics be used to predict plant invasions along rivers? J Biogeogr 29:535-43.

Clausen P, Nolet BA, Fox AD, Klaassen M. 2002. Long-distance endozoochorous dispersal of submerged macrophyte seeds by migratory waterbirds in northern Europe-a critical review of possibilities and limitations. Acta Oecol 23:191-203. 
Davies BR, Biggs J, Williams PJ, Lee JT, Thompson S. 2008. A comparison of the catchment sizes of rivers, streams, ponds, ditches and lakes: implications for protecting aquatic biodiversity in an agricultural landscape. Hydrobiologia 597:7-17.

Donald PF, Evans AD. 2006. Habitat connectivity and matrix restoration: the wider implications of agri-environment schemes. J Appl Ecol 43:209-18.

Fahrig L. 2003. Effects of habitat fragmentation on biodiversity. Annu Rev Ecol Evol Syst 34:487-515.

Foley JA, DeFries R, Asner GP, Barford C, Bonan G, Carpenter SR, Chapin FS, Coe MT, Daily GC, Gibbs HK, Helkowski JH, Holloway T, Howard EA, Kucharik CJ, Monfreda C, Patz JA, Prentice IC, Ramankutty N, Snyder PK. 2005. Global consequences of land use. Science 309:570-4.

Geertsema W. 2005. Spatial dynamics of plant species in an agricultural landscape in the Netherlands. Plant Ecol 178:23747.

Geertsema W, Sprangers JTCM. 2002. Plant distribution patterns related to species characteristics and spatial and temporal habitat heterogeneity in a network of ditch banks. Plant Ecol 162:91-108

Geertsema W, Opdam P, Kropff MJ. 2002. Plant strategies and agricultural landscapes: survival in spatially and temporally fragmented habitat. Landscape Ecol 17:263-79.

Greene DF, Johnson EA. 1989. A model of wind diepsral of winged or plumed seeds. Ecology 70:339-47.

Groves JH, Williams DG, Caley P, Norris RH, Caitcheon G. 2009. Modelling of floating seed dispersal in a fluvial environment. River Res Appl 25:582-92.

Gurnell AM, Boitsidis AJ, Thompson K, Clifford NJ. 2006. Seed bank, seed dispersal and vegetation cover: colonization along a newly-created river channel. J Veg Sci 17:665-74.

Hanski I. 2005. Landscape fragmentation, biodiversity loss and the societal response-the longterm consequences of our use of natural resources may be surprising and unpleasant. EMBO Rep 6:388-92.

Hirose T, Werger MJ. 1995. Canopy structure and photon flux partitioning among species in a herbaceous plant community. Ecology 76:466-74

Jansson R, Nilsson C, Renofalt B. 2000. Fragmentation of riparian floras in rivers with multiple dams. Ecology 81:899903.

Jansson R, Zinko U, Merritt DM, Nilsson C. 2005. Hydrochory increases riparian plant species richness: a comparison between a free-flowing and a regulated river. J Ecol 93:1094103.

Jermy AC, Tutin TG. 1968. British sedges. A handbook of the species of Carex found growing in the British isles. London: Botanical society of the Bristish isles.

Kahle P, Tiemeyer B, Eichler-Löbermann B, Lertnartz B. 2008. Phosphorus losses from an agriculturally used lowland catchment in North-Eastern Germany. Wasserwirtschaft 98:10-15.

Karssenberg D, de Jong K, van der Kwast J. 2007. Modelling landscape dynamics with Python. Int J Geogr Inf Sci 21:483-95.

Kleyer MR, Bekker M, Knevel IC, Bakker JP, Thompson K, Sonnenschein M, Poschlod P, van Groenendael JM, Klimes L, Klimesová J, Klotz S, Rusch GM, Hermy M, Adriaens D, Boedeltje G, Bossuyt B, Dannemann A, Endels P, Götzenberger L, Hodgson JG, Jackel A-K, Kühn I, Kunzmann D, Ozinga WA, Römermann C, Stadler M, Schlegelmilch J, Steendam HJ, Tackenberg O, Wilmann B, Cornelissen JHC,
Eriksson O, Garnier E, Peco B. 2008. The LEDA Traitbase: a database of life-history traits of Northwest European flora. J Ecol 96:1266-74.

KNMI. 2011. Klimatologie. Informatie over Het Weer in het Verleden KNMI.

Kröger R, Moore MT, Farris JL, Gopalan M. 2011. Evidence for the use of low-grade weirs in drainage ditches to improve nutrient reductions from agriculture. Water Air Soil Pollut $221: 223-34$

Lamers LPM, Smolders AJP, Roelofs JGM. 2002. The restoration of fens in the Netherlands. Hydrobiologia 478:107-30.

Leng X, Musters CJM, de Snoo GR. 2011 . Effects of mowing date on the opportunities of seed dispersal of ditch bank plant species under different management regimes. J Nat Conserv 19:166-74.

Levine JM. 2003. A patch modeling approach to the communitylevel consequences of directional dispersal. Ecology 84:1215-24

Maljanen M, Sigurdsson BD, Guömundsson J, Öskarsson H, Huttunen JT, Martikainen PJ. 2010. Greenhouse gas balances of managed peatlands in the Nordic countries present knowledge and gaps. Biogeosciences 7:2711-38.

Merritt DM, Wohl EE. 2006. Plant dispersal along rivers fragmented by dams. River Res Appl 22:1-26.

Middleton B, van Diggelen R, Jensen K. 2006. Seed dispersal in fens. Appl Veg Sci 9:279-84.

Milsom TP, Sherwood AJ, Rose SC, Town SJ, Runham SR. 2004. Dynamics and management of plant communities in ditches bordering arable fenland in eastern England. Agric Ecosyst Environ 103:85-99.

Monteith JL. 1973. Principles of environmental physics. London: Edward Arnold

Moore MT, Kröger R. 2011. Evaluating plant species-specific contributions to nutrient mitigation in drainage ditch mesocosms. Water Air Soil Pollut 217:445-54.

Moss B. 1983. The Norfolk Broadland: experiments in the restoration of a complex wetland. Biol Rev 58:521-61.

Nathan R. 2001. Dispersal biogeography. In: Levin SA, Ed. Encyclopedia of biodiversity. New York: Academic Press. p 127-52.

Nathan R, Katul GG, Horn HS, Thomas SM, Oren R, Avissar R, Pacala SW, Levin SA. 2002. Mechanisms of long-distance dispersal of seeds by wind. Nature 418:409-13.

Nathan R, Katul GG, Bohrer G, Kuparinen A, Soons MB, Thompson SE, Trakhtenbrot A, Horn HS. 2011. Mechanistic models of seed dispersal by wind. Theor Ecol 4:113-32.

Nilsson C, Brown RL, Jansson R, Merritt DM. 2010. The role of hydrochory in structuring riparian and wetland vegetation. Biol Rev 85:837-58.

Ouborg NJ, Piquot Y, van Groenendael JM. 1999. Population genetics, molecular markers and the study of dispersal in plants. J Ecol 87:551-68.

Ozinga WA, Römermann C, Bekker RM, Prinzing A, Tamis WLM, Schaminée JHJ, Hennekens SM, Thompson K, Poschlod P, Kleyer M, Bakker JP, van Groenendael JM. 2009. Dispersal failure contributes to plant losses in NW Europe. Ecol Lett 12:66-74.

Pelacani S, Märker M, Rodolfi G. 2008. Simulation of soil erosion and deposition in a changing land use: a modelling approach to implement the support practice factor. Geomorphology 99:329-40.

Säumel I, Kowarik I. 2010. Urban rivers as dispersal corridors for primarily wind-dispersed invasive tree species. Landsc Urban Plan 94:244-9. 
Sarneel JM, Beltman B, Buijze A, Groen R, Soons MB. The role of wind in the dispersal of floating seeds in slow-flowing or stagnant water bodies. J Veg Sci (in press).

Schneider RL, Sharitz RR. 1988. Hydrochory and regeneration in a bald cypress water tupelo swamp forest. Ecology 69:105563.

Soomers H, Winkel DN, Du Y, Wassen MJ. 2010. The dispersal and deposition of hydrochorous plant seeds in drainage ditches. Freshw Biol 55:2032-46.

Soons MB. 2006. Wind dispersal in freshwater wetlands: knowledge for conservation and restoration. Appl Veg Sci 9:271-8.

Soons MB, Heil GW. 2002. Reduced colonization capacity in fragmented populations of wind-dispersed grassland forbs. J Ecol 90:1033-43.

Soons MB, Heil GW, Nathan R, Katul GG. 2004. Determinants of long-distance seed dispersal by wind in grasslands. Ecology 85:3056-68.

Soons MB, Messelink JH, Jongejans E, Heil GW. 2005. Habitat fragmentation reduces grassland connectivity for both shortdistance and long-distance wind-dispersed forbs. J Ecol 93:1214-25.

Soons MB, van der Vlugt C, van Lith B, Heil GW, Klaassen M. 2008. Small seed size increases the potential for dispersal of wetland plants by ducks. J Ecol 96:619-27.

Strykstra RJ, Verweij GL, Barker JP. 1997. Seed dispersal by mowing machinery in a Dutch brook valley system. Acta Bot Neerlandica 46:387-401.
Tackenberg O. 2003. Modeling long-distance dispersal of plant diaspores by wind. Ecol Monogr 73:173-89.

Thomson FJ, Moles AT, Auld TD, Ramp D, Ren S, Kingsford RT. 2010. Chasing the unknown: predicting seed dispersal mechanisms from plant traits. J Ecol 98:1310-18.

Van den Broek T, van Diggelen R, Bobbink R. 2005. Variation in seed buoyancy of species in wetland ecosystems with different flooding dynamics. J Veg Sci 16:579-86.

Van der Meijden R. 2005. Heukels' flora van Nederland. Groningen: Wolters-Noordhoff.

Van Loon AH, Schot PP, Bierkens MFP, Griffioen J, Wassen MJ. 2009. Local and regional impact of anthropogenic drainage on fen contiguity. Hydrol Earth Syst Sci 13:1837-48.

Van Strien AJ, van der Linden J, Melman TCP, Noordervliet MAW. 1989. Factors affecting the vegetation of ditch banks in peat areas in the western Netherlands. J Appl Ecol 26:9891004.

Vaughan RE, Needelman BA, Kleinman PJA, Allen AL. 2007. Vertical distribution of phosphorus in agricultural drainage ditch soils. J Environ Qual 36:1895-903.

Verhoeven JTA, Soons MB, Janssen R, Omtzigt N. 2008. An operational landscape unit approach for identifying key landscape connections in wetland restoration. J Appl Ecol 45:1496-503.

Wichmann MC, Alexander MJ, Soons MB, Galsworthy S, Dunne L, Gould R, Fairfax C, Niggemann M, Hails RS, Bullock JM. 2009. Human-mediated dispersal of seeds over long distances. Proc R Soc B 276:523-32. 